\title{
Vaginal Soft Tissue Neoplasm
}

National Cancer Institute

\section{Source}

National Cancer Institute. Vaginal Soft Tissue Neoplasm. NCI Thesaurus. Code C40265.

A benign or malignant mesenchymal neoplasm of the vagina. Representative examples

include leiomyoma, rhabdomyoma, leiomyosarcoma, endometrioid stromal sarcoma, and botryoid-type embryonal rhabdomyosarcoma. 